\title{
RELATIVE VALUATION MODEL ANALYSIS OF IDX LQ45 STOCKS
}

\author{
Dian K. Inezwari ${ }^{1}$ \\ PT. ALM Capital Indonesia
}

\begin{abstract}
There are various valuation models can be used by investors in order to predict the stock value. This paper focuses on the Relative Valuation Model, which is the popular model used by investors as it is easier to use compared to other models. The aim of this paper is to compare the prediction accuracy of various ratios in the model. Ratios examined in this paper are Price to Earning (PE), Price to Book Value (PBV), Price to Cash Flow (PCF), and Price to Sales (PS). Using the LQ45 listed stocks during period 2006 - 2010, it is found that, overall, PBV appears to be the best ratio to predict LQ45 stocks in Indonesian equity market. However, mixed results are found in the yearly analysis, in which PE, PBV, and PCF result in lower prediction errors, in different years. In the sector industry analysis, both PE and PBV are the best predictors in three sectors each. The descriptive analysis is supported by the hypo research testing that shows the accuracy of examined ratios is different. The research result implication is that investors should take time and sectors into the account before choosing a single ratio as a predictor.
\end{abstract}

Keywords: relative valuation, price to earnings, price to book value, price to cash flow, price to sales, prediction accuracy.

\section{BACKGROUND}

For many people, get prepared on their future need is a must. They will save their money for their future plan. Commonly, they will invest their money to get a return to fulfill their future needs. In term

\footnotetext{
${ }^{1}$ PT. ALM Capital Indonesia, Wisma GKBI, Jl. Jend. Sudirman Kav.28 Lt.5 Suite 515 (inezwari@yahoo.com).
} 
of financial assets investment, people can invest either in money market or capital market. Both markets offer different instrument of investment with different rate of return and length of time. Money market offers instrument of investment such as; saving deposit, term deposit and SBI. Each instrument offers different rate of return. Based on data released by Bank of Indonesia in 2010, saving deposits in Indonesia offer around 3\% rate of return for one year, term deposit for three months offer rate of return around $7 \%$, for six months term deposit offers around $8 \%$ and one year term deposits offer $9.5 \%$.

Table 1. Rate of Return in Indonesia Money Market, June 2011

\begin{tabular}{|l|r|}
\hline Instrument & Return \\
\hline Saving Deposit & $3 \%$ \\
Term Deposit - three months & $7 \%$ \\
Term Deposit - six months & $8 \%$ \\
Term Deposit - 12 months & $9.5 \%$ \\
3 Months SBI & $6.5 \%$ \\
\hline
\end{tabular}

Source: Website BI

Table 2 shows that in past few years capital market in Indonesia shows significant raise in its performance, especially in stock market. Based on Author's calculation, Jakarta Composite Index recorded average of return as $23.2 \%$ in aggregate five years from 2006 until 2010. In period of research, from 2006 - 2010, JCI almost always recorded return above 25\% except for 2008. In 2008, the return is negative because the impact of financial crisis. But in the next year, JCI recorded increase of return as $61 \%$.

Table 2. JCI Rate of Return

\begin{tabular}{|c|c|}
\hline \multicolumn{2}{|c|}{ JCI Return } \\
\hline 2006 & $44.50 \%$ \\
2007 & $41.30 \%$ \\
2008 & $-68.80 \%$ \\
2009 & $61.00 \%$ \\
2010 & $38.00 \%$ \\
\hline
\end{tabular}


Other instrument from capital market is bonds, which is offer another level of return with different tenor. Based on Indonesia Bond Price Agency, in Indonesia one year corporate bonds offer around 5.7\% rate per annum, $6.2 \%$ for three years bonds and the highest is for 15-years bonds that offer coupon rate around $8.2 \%$. Table 3 will show the yield of Indonesia's corporate bonds.

Table 3. Yield of Indonesia Corporate Bonds

\begin{tabular}{|c|c|}
\hline \multicolumn{2}{|c|}{ Yield of Indonesia } \\
Corporate Bond \\
\hline One year & $5.70 \%$ \\
Three year & $6.20 \%$ \\
10-year & $7.50 \%$ \\
12-year & $7.80 \%$ \\
15-year & $8.20 \%$ \\
\hline \multicolumn{2}{|c|}{ Source: Website IBPA }
\end{tabular}

Nowadays stock is one of popular media investment that offered in different industries with different type, and different level of price. To enter the stock market, investor should have a good investment strategy. In choosing stocks, usually the stock price will be the first thing to consider and evaluate whether the stock is cheap or expensive compared to fundamental of companies.

As a consideration to develop an investment strategy, generally investor will examine the fundamental of stock. To find out about the fundamental value of the stocks, some models of stock price valuation can be generated to appraise it. The models that used in stock price valuation should be reliable and apply of consistencies of same criteria time after time. One reason of using models in valuation is that the models are never vary and never moody in contrary of human forecaster that more natural to react emotionally and inconsistent (O'Shaughnessy, 1998) so that's why the models of stock price valuation can be used objectively.

There are many models to value stocks from a simple one to complex. Damodaran (2006) explains some valuation models such as; AssetBased Valuation, Discounted Cash Flow Models, Relative Valuation 
and Contingent Claim Models. Each model has different assumptions and factors, therefore the final value derived from each model can be very different. The common models in predict a stock price usually is Relative Valuation, almost $85 \%$ of equity research reports in US are based upon a multiple and comparables. (Damodaran, 2006)

This research will focus on some models of Relative Valuation model. Some relative valuation methods that will be examined in this study are Price to Earnings Ratio (P/E), Price to Book Value Ratio (P/BV), Price to Cash Flow (P/CF), Price to Sales (P/S) and Changes of Earning per Shares (\% EPS). These methods are the most popular methods used by investors in various markets in the world (O’Shaughnessy, 1998)

Those models will produce the forecasted share prices and compared their accuracies in predicting stock price in short period. By comparing the prediction errors, the best of Relative valuation model can be determined. The result of this research provides practical information with regards the best model used to predict the stock price in IDX.

The purpose of this study is to investigate the ability of average P/E, $\mathrm{PBV}, \mathrm{P} / \mathrm{CF}, \mathrm{P} / \mathrm{Sales}$, EPS changes to predict future stock price in Indonesian equity markets.

\section{LITERATURE REVIEW}

\section{Valuation}

Decision making in investing usually need a valuation. Various kind of valuation can be used either its the simple or the complex one. Usually a simple valuations use a limited amount of information which is begin with multiple analysis that uses a few number of financial statement account like sales, earnings or book value. Simple methods run the risk of ignoring relevant information. In contrary, a complex fundamental analysis indentifies all relevant information and extracts the implications of that information for valuing the firm.

Berk (2000) define the valuation principle as follow, "The value of a commodity or an asset to the firm or its investors is determined by its 
competitive market price. The benefit and costs of a decision should be evaluated using those market prices. When the value of the benefits exceeds the value cost, the decision will increase the market value of the firm."

According to Damodaran (2006) valuation approaches are used in investment because there is perception that the market are inefficient and the price in the market is incorrect. It means that in investor's perception the market price of stock could be undervalued or overvalued and it will be corrected to the fair value. In an efficient market, the market price is the best estimation of stock value.

\section{Valuation Approaches}

Some approaches in valuation usually mentioned in the investment literature are Discounted cash-flow (DCF) method, Relative valuation method (multiple method), and Conteingent claims valuation method.

Figure 1 shows the approaches of valuation which is classified by Damodaran. The purpose of asset based valuation approach is to value whether the asset owned by company is worth or not for its business. In term of to calculate the expected future cash flow, discounted cash flow approach is used by relating the value of an asset to the present value of expected cash flow that can be generate from that asset. Basis in discounted cash flow is every asset has an intrinsic value that can be estimated, based upon its characteristics in terms of cash flows, growth and risk. In conduct discounted cash flow valuation we need to estimate the life of the asset, to estimate the cash flows during the life of the asset, to estimate the discount rate to apply to these cash flows to get present value. (Damodaran, 2006) 


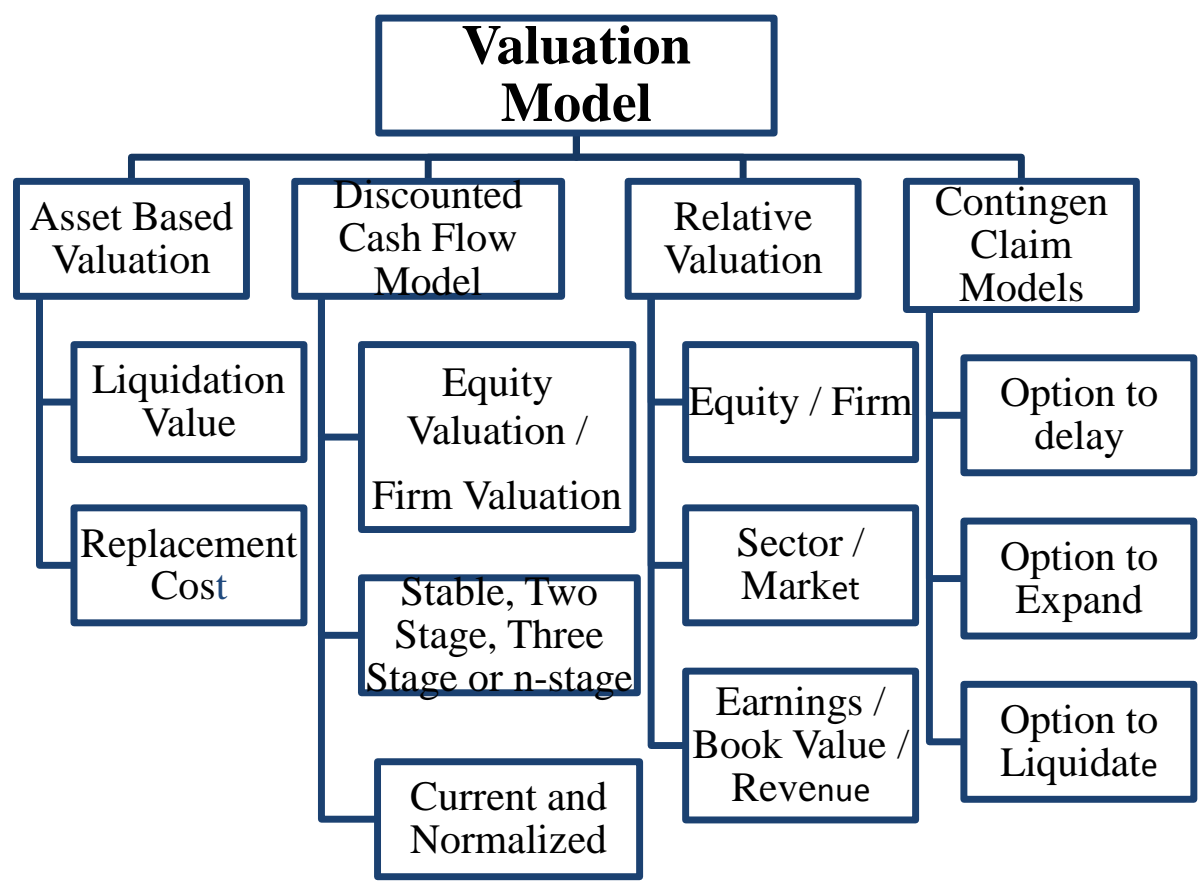

(Source, Damodaran, 2006)

Figure 1. Valuation Models

The most commonly used valuation approach is relative valuation. This approach estimate value of asset by comparing a comparable variable like earnings, cash flows, book value or sales with other company. Last approach based on scheme 2.1 is contingent claim valuation that using option pricing model to measure the value of an asset.

\section{Relative Valuation}

The objective of relative valuation is to value assets based on how similar assets are currently priced in the market. In simply way, firms in the same business as the firm being valued are called comparable.

Damodaran (2006) stated that the value of assets in relative valuation are derived from pricing of comparable asset or business by using 
variable such as earning, book value, revenue or cash flow. So it compares the earning, book value, revenue or cash flow of company which is has similar amount of asset or business to get the value of each company within their industry.

Relative valuation is more likely to reflect market perceptions than oher approach of valuation. It formed by volatility of price which is depend on market situation. Damodaran (2006) argued that it is important that the price reflect these perceptions as is the case when the investment objectives are to sell a security at that price today (as in the case of an IPO) and to invest on the "momentum" based strategies. (Damodaran, 2006)

Another description of relative valuation model is provided by Brown (2009) is "Relative valuation implicitly contends that it is possible to determine the value of an economic entity (i.e., the market, an industry, or a company) by comparing it to similar entities on the basis of several ratios that compare its stock price to relevant variables that affect a stock's value." Meanwhile, Penman (2007) stated that relative or multiple is only the ratio of the stock price to a particular variable in the financial statements. The most common ratios derived by important numbers in the statement such as earnings, book values, sales and cash flow, hence the price-earnings ratio $(\mathrm{P} / \mathrm{E})$, the price to book ratio (P/BV), the price to sales ratio (P/S) and the price to cash flow from operation $(\mathrm{P} / \mathrm{CF})$.

The summary of explanation above is that relative valuation can be applied for similar firms in the market by comparing some variables such as the earnings firms generate, to the book value or replacement value of the firms themselves, to the revenues that firms generate or to measures that are specific to firms in a sector.

There are some advantages of relative valuation:

1. Relative valuation is much more likely to reflect market perceptions and moods than discounted cash flow valuation.

2. With relative valuation, there will be a proportion of securities that are undervalued and overvalued.

3. Relative valuation is more tailored to investor needs.

4. Relative valuation generally requires less information than other valuation method. 
Some disadvantages of relative valuation:

1. Relative valuation is built on the assumption that markets are correct in the aggregate, but make mistakes on individual securities. To the degree that markets can be over or under valued in the aggregate, relative valuation will fail

2. Relative valuation may require less information in the way its just use a variable to value.

Relative valuation is easiest to use when there are a large number of assets comparable to the one being valued, these assets are priced in a market, and there exists some common variable that can be used to standardize the price. This approach tends to work best for investors who have relatively short time horizons, are judged based upon a relative benchmark, can take actions that can take advantage of the relative mispricing; for instance, a hedge fund can buy the undervalued and sell the overvalued assets.

\section{Price to Earnings Ratio}

The most common valuation multiple is the price earnings ratio. $\mathrm{P} / \mathrm{E}$ ratio is equal to the share price divided by its earnings per share. This formula indicates when buying stocks, investor in sense buying the rights to the firm's future earnings. Investor should be willing to pay more for a stock with higher current earnings. The value can be estimated by multiplying its current earnings per share by the average $\mathrm{P} / \mathrm{E}$ ratio of comparable firms. $\mathrm{P} / \mathrm{E}$ ratio compares the value of expected future earnings to current earnings. The $\mathrm{P} / \mathrm{E}$ ratio is based on expected earnings that have not yet been recognized.

O'Shaughnessy (1998) argued that buying stocks with low P/E is the one true faith. Investors who buy stocks with low PE think they're getting a bargain. Generally, investors believe that when a stock's PE ratio is high, investors have unrealistic expectations for the earnings growth of the stock.

Damodaran (2006) explained that one of the more intuitive ways to think of the value of any asset is as a multiple of the earnings that assets generate. When buying a stock, it is common to look at the price paid as a multiple of the earnings per share generated by the company. This price/earnings ratio can be estimated using current 
earnings per share, which is called a trailing PE, or an expected earnings per share in the next year, called a forward PE.

There are two types of P/E. Firstly, the Trailing P/E that is calculation of firm's $\mathrm{P} / \mathrm{E}$ using earnings over the prior 12 months. Secondly, the Forward $\mathrm{P} / \mathrm{E}$ that is firm's $\mathrm{P} / \mathrm{E}$ ratio calculated using predicted earnings over the coming 12 months.

A higher P/E ratio means that investors are paying more for each unit of net income, so the stock is more expensive compared to one with a lower $\mathrm{P} / \mathrm{E}$ ratio. The $\mathrm{P} / \mathrm{E}$ ratio also shows current investor demand for a company share.

The most common approach to estimating the PE ratio for a firm is to choose a group of comparable firms calculate the average PE ratio and subjectively adjust the average for differences between the firm being valued and the comparable firms.

Penman (2007) mentioned the biggest advantage of the $\mathrm{P} / \mathrm{E}$ ratio is that it is easy to use and understand. Even those who are not educated in finance can understand it, and although it is only a very basic tool and method of evaluating the worth of the shares of a company, it can be used to make quick decisions.

Although the $\mathrm{P} / \mathrm{E}$ ratio has some disadvantages such as, $\mathrm{P} / \mathrm{E}$ is largely due to the subjective in nature, and that no standard in what price earnings ratio investor can sell at. The other disadvantage is inflation. At times of high inflation, the currency of the specific country where the share observation takes place. The problem with this is that if investor exchanges the earnings of the company to a foreign currency, say from USD to IDR, it can devaluate the earnings of the company, which in turn, given the formula, increases P/E. The interpretation of the $\mathrm{P} / \mathrm{E}$ concerning a company is also dilemmatic. Some investors might consider a specific $\mathrm{P} / \mathrm{E}$ ratio too high, whereas others might consider the same ratio to be too low, even if it is compared with the industry $\mathrm{P} / \mathrm{E}$ average.

There are some important issues that have to be considered when using $\mathrm{P} / \mathrm{E}$ ratio; (1) it is the reflection of the market's optimism concerning a firm's growth prospects, (2) it is a much better indicator 
of a stock's value than the market price alone, (3) in general, it is difficult to say whether a particular P/E is high or low, and (4) P/E ratios are generally lower during times of high inflation.

\section{Price to Book Value Ratio}

Firms usually trade at a price that differs from book value. The book value represents shareholders' investment in the firm. Book value is also assets minus liabilities that are equal to net assets. But, actually book value typically does not measure the value of the shareholders' investment. The value of the shareholders' and the value of net assets are based on how much the investment is expected to earn in the future. Accordingly, the intrinsic $\mathrm{P} / \mathrm{BV}$ ratio is determined by the expected return on the book value.

$\mathrm{P} / \mathrm{BV}$ ratio fits with the idea that shareholders buy earnings. Price, in the numerator of the $\mathrm{P} / \mathrm{BV}$ ratio is based on the expected future earnings that investors buying. So, the higher the expected earnings relative to book value, the higher $\mathrm{P} / \mathrm{BV}$ ratio. The $\mathrm{P} / \mathrm{BV}$ ratio prices expected return on book value, but it does not price a return that is equal to the required return on book value.

O'Shaugnessy (1998) called $\mathrm{P} / \mathrm{BV}$ as a better gauge of value. Essentially, investors who buy stocks with low PBV believe they are getting stocks at a price close to their liquidating value, and that they will be rewarded for not paying high prices for assets.

The relationship between price and book value of a firm has always attracted attention for investor. If the stock sold below the book value, it has been generally considered as a good candidate for undervalued portfolios, while those selling higher than book value are considered as overvalued.

Damodaran (2006) stated that "The market value of the equity in a firm reflects the market's expectation of the firm's earning power and cash flows. The book value of equity is the difference between the book value of assets and the book value of liabilities."

Penman (2007) described $\mathrm{P} / \mathrm{BV}$ as follow, "The P/BV ratio is a financial ratio used to compare a company's book value to its current market price. Book value is an accounting term denoting the portion 
of the company held by the shareholders; in other words, the company's total tangible assets less its total liabilities."

The calculation of $\mathrm{P} / \mathrm{BV}$ can be performed in two ways, but the result should be the same each way. In the first way, the company's market capitalization can be divided by the company's total book value from its balance sheet. The second way, using per-share values, is to divide the company's current share price by the book value per share (book value divided by the number of outstanding shares).

LeRiche (2009) stated that "as with most ratios, it varies a fair amount by industry. Industries that require more infrastructure capital will usually trade at $P / B$ ratios. $P / B$ ratios also commonly used to compare banks, because most assets and liabilities of banks are constantly valued at market values."

A higher $\mathrm{P} / \mathrm{B}$ ratio implies that investors expect company to make more value from a given of assets. $\mathrm{P} / \mathrm{B}$ ratios do not, however, directly provide any information on the ability of the firm to generate profits or cash for shareholders. There are several reasons why Price to Book value ratio useful in investment analysis: first, book value provides a relatively stable, intuitive measure of value that can be compared to the market price. Second, book value give a reasonably consistent accounting standard across firms, so this ratio can be compared across similar firms. Third, even firms with negative earnings, which is cannot be measured using PE ratio, can be valued using this ratio.

One of the advantages of the price/book ratio is that it is easy to calculate it and understand the meaning behind the numbers. As a result the knowledge of such a ratio will greatly facilitate the comparison between stocks target, especially those that are part of old-line industries. Price/book ratios give an understanding of how the market values the assets as compared to the earnings it makes. What is more, price/book ratio is applicable throughout the world.

On the other hand, price/book value fails to reflect intangible assets such as intellectual assets, which represent the basis of the functions of high-tech companies. As a result, the balance sheets of such companies fail to reflect the intellectual assets of such companies. In 
turn, this leads to low book values and artificially high price/book ratios.

\section{Price to Cash Flow Ratio}

Since the concern of window dressing has risen, the popularity of the relative price to cash flows valuation ratio are growth. Cash flow values are generally less prone to manipulation than other variables. Brown (2009) stated that cash flow values are important in fundamental valuation, and they critical when doing credit analysis where "cash is king."

The price/cash flow ratio is a ratio used to compare a company's market value to its cash flow. It is calculated by dividing the company's market cap by the company's operating cash flow or, equivalently, divide the stock price by the operating cash flow per share. In theory, the lower a stock's price/cash flow ratio is, the better value that stock is.

The accounting rules sometimes cause certain types of businesses or industries to understate or overstate the true profits, causing the price to cash flow ratio to work better for valuation purposes than its counterpart, the price to earnings ratio. For some company, the price to cash flow ratio would provide a better idea of the amount of money available to management for further research and development, marketing support, debt reductions, dividends, share repurchases, and more. (Penman, 2007)

Turk (2006) mentioned cash flow per share ratio is another important ratio in determining company's earnings. While this ratio does not relate to a company's earnings in the strictest sense, it does indeed give a picture of how much cash is flowing through the company during the course of a given year. If the business is operating properly, high percentage of this cash will comprise earnings. Some financial analysts give the cash flow per share ratio more bearing than earnings per share, because the earnings per share figure can be subject to manipulation, whether inadvertent or fraudulent. On the other hand, it is almost impossible to fraudulently manipulate cash as it is a highly physical asset, and very easy to verify. 
Price to cash flow represents another measurement of the company's earnings power, or how much it can generate for its shareholders. However, price/cash flow has its disadvantages. One of them is that it is not easy to calculate it and it is also difficult to define what a cash flow is.

\section{Price to Sales Ratio}

A revenue multiple measures the value of the equity or a business relative to the revenue that it generates. Revenue multiple have number of reasons to be used in investment analysis, such as: unlike earnings and book value ratios, which can become negative in some firms, revenue multiples are available even for the most troubled firm and very young or new firms. Revenue multiples is relatively difficult to manipulate. O'Shaughnessy (1998) called price to sales ratio as The King of the Value Factors.

The Price to sales ratio has been suggested as useful by Martin Leibowitz (1997), a widely admired stock and bond portfolio manager. These advocates consider this ratio meaningful and useful for two reasons. First, they believe that strong and consistent sales growth is a requirement for a growth company. Second, given all the data in the balance sheet and income statement, sales information is subject to less manipulation than any other data item. (Brown, 2009)

Price-to-sales ratio, $\mathrm{P} / \mathrm{S}$ ratio, or PSR, is a valuation metric for stocks. It is calculated by dividing the company's market cap by the company's revenue in the most recent year; or, equivalently, divide the per-share stock price by the per-share revenue.

Both earnings and book value are accounting measures and are determined by accounting rules and principles. An alternative approach, which is far less affected by accounting choices, is to use the ratio of the value of an asset to the revenues it generates. For equity investors, this ratio is the price/sales ratio (PS), where the market value per share is divided by the revenues generated per share. The advantage of using revenue multiples, however, is that it becomes far easier to compare firms in different markets, with different accounting systems at work, than it is to compare earnings or book value multiples. 
Some advantages of Price to Sales ratio are: since the sales revenue is always positive, the price to sales ratio is meaning full even firm is in distress, sales revenue is not as easy to manipulate as EPS and book value, which are significantly affected by accounting conversation, $\mathrm{P} / \mathrm{S}$ ratios is not as volatile as $\mathrm{P} / \mathrm{E}$ multiple, For start-up companies $\mathrm{P} / \mathrm{S}$ is an appropriate measure whereas the $\mathrm{P} / \mathrm{E}$ may be misleading. It is also a valuable tool for cyclical or mature industries

On the other hand, some disadvantages of Price to Sales ratio are: if firms made significant amount of sales on credit, that will inflate their Price to Sales ratio, but that does not necessarily indicate operating profits as measured by earnings and cash flow, furthermore, analyst should be careful about the revenue recognition practices that can still distort sales forecast thus $\mathrm{P} / \mathrm{S}$ ratio, $\mathrm{P} / \mathrm{S}$ ratios can capture the sales part, but it cannot capture the differences in cost structure across companies.

\section{Previous Studies}

Relative valuation are widely used in some countries around the world. Some research had been conducted in term of using the relative models in predicting the stock price. Price earnings ratio, Price to book value ratio, Price to sales ratio and Price to cash flow ratio are the most generally use as the object of researches. Park and Lee (2003) conducted a research that test the relevance of relative valuation models in Japan stock market. Omran (2009) conducted the research about the valuation multiples of Islamic financial institution in UAE. Sehgal and Pandey (2010) conducted a research about equity valuation using price multiple in Indian companies. Minjina (2009) conducted a research of relative performance using multiples in Bucharest stock exchange.

The result from each research are different. Park and Lee found that the PBV gives rise to least prediction errors in Japan Stock market while Omran (2009) results is PE ratio for Islamic financial institution in UAE and also Sehgal and Pandey found that PE is the best approach for equity valuation in the Indian context and Minjina's results indicate that the best accuracy is determined by the $\mathrm{P} / \mathrm{CF}$ multiple. 
Based on Park and Lee (2003), PBV gives rise to least prediction errors in Japan Stock market. By comparing zero-net portfolios' returns, they found that $\mathrm{P} / \mathrm{S}$ ratio is related to the best investment strategy in the period, but PER is a reasonably good multiple in the bear market period. Omran (2009) observed that the price-to-earnings ratio provides the best price forecast (and hence the minimum pricing errors) for most of the sample sectors. Further, price to book value seems to be the second-best financial ratio for equity valuation. P/E also performs best vis à vis other multiples on an aggregate market basis. Minjina (2009) results also show that the P/S multiple has a lower accuracy than those of the valuation methods compared to which it is statistically different.

\section{RESEARCH METHODOLOGY}

\section{Stock Selection}

Data that will be used in this research are listed stocks in Indonesia Stock Exchange that had been listed in LQ45 index during 2006 2010. The stock in LQ45 are frequently changed and this research use the stocks that ever listed as LQ45 within the period. As a result, the total company used in this research is 86 companies. These companies will be classified into nine sectors that available in Indonesia Stock Exchange. Number of company for each sector are listed in Table 4 below.

Table 4 Number of Company for Each Sector

\begin{tabular}{|c|c|}
\hline Sector & $\begin{array}{c}\text { Number of } \\
\text { Company }\end{array}$ \\
\hline Banking & 12 \\
Basic Industry & 9 \\
Consumer & 5 \\
Infrastructure & 11 \\
Plantation & 7 \\
Mining & 13 \\
Other Industry & 4 \\
Property & 13 \\
Trade, Service & 12 \\
\hline Total & 86 \\
\hline
\end{tabular}




\section{Relative Valuation Methods}

This research will conduct calculation of relative valuation models: price to earnings ratio, price to book value, price to cash flow, and price to sales ratio. Each model will be calculated individually and the companies will be classified based on sector industry category. The formulas of each model that will be used in this research are:

1. Price to Earnings Ratio :

2. Price to Book Value :

3. Price to Cash Flow :

4. Price to Sales :

The four models can be calculated if the denominator such as EPS, book value per share, sales per share and cash flow per share show positive number. So the company which has the negative value of each denominator in each year will be removed from the sample.

To get the average industry ratio, the data will be classified into nine sectors as listed in Table 4 and this average industry will be used to calculate the predicted stock price by multiplying it with the denominator of each ratio: EPS, book value per shares, sales per shares and cash flow per shares. After getting the predicted price, it will be compared to the actual price at the end of the year. The difference between predicted and actual price are the prediction error values. In order to rank the accuracy of the predicting model, the prediction error values will be made absolute. The model with the lowest absolute prediction errors is the best model in predicting stock price.

\section{Hyporesearch}

There are many methods in stock price valuation. The better method is method that could make better prediction and expected to have small errors by compare the result with the actual price. This research will focus on relative valuation method and use four models in predicting the stock price. The objective of this research is to compare the level of error from each relative valuation models. The research problems induced the following hyporesearch:

$\mathrm{H}_{0}$ : All models have same level of error in predicting stock price 
$\mathrm{H}_{1}$ : The models will show different level of error in predicting stock price

Or,

$\mathrm{H}_{0}: \mu_{\mathrm{PE}}=\mu_{\mathrm{PS}}=\mu_{\mathrm{PBV}}=\mu_{\mathrm{PCF}}$

$\mathrm{H}_{1}: \mu_{\mathrm{PE}} \neq \mu_{\mathrm{PS}} \neq \mu_{\mathrm{PBV}} \neq \mu_{\mathrm{PCF}}$

\section{Data analysis procedure}

To achieve the purpose of this research, some steps are designed:

1. Identify sample companies. The companies that will be included in this research are all companies that ever had been listed in LQ45 index. The final samples consist of 86 companies.

2. Classified sample by it industry. The final sample will be classified to nine sectors that listed in Indonesia Stock Exchange: banking, basic industry, consumer, infrastructure, plantations, mining, other industry, property and trade and services.

3. Calculate the value of each model and predict the stock price. Calculate the value of $\mathrm{P} / \mathrm{E}, \mathrm{P} / \mathrm{BV}, \mathrm{P} / \mathrm{CF}$, and $\mathrm{P} / \mathrm{S}$ of companies and calculate the average of each model by industry. The average value will be used for predicting stock price in the next year by multiplying it with the denominator of each model.

4. Calculate error of models. Compare the stock price prediction with the actual price. The differences between the prediction and actual is the error of models.

5. The number of prediced error value will be made absolute, so all of the number will appear as positive number.

6. Calculate the average of absolute predicted error value to get the best model in predicting stock price which has the smallest number of error.

7. Test the average predicted error value by using statistical method to determine whether each average show a different number or not each other. The statistic method in this research is one way anova.

8. The result of statistical test is used for answer the hyporesearch of this research.

This research will investigate the best model in predicting stock price in aggregate five years from 2006 until 2010, split to each year and split to each industry. The statistical test is only apply for the error predicted values in aggregate five years. 
As a result, this research will show which relative valuation model between $\mathrm{PE}$ ratio, $\mathrm{P} / \mathrm{BV}$ ratio, $\mathrm{P} / \mathrm{S}$ ratio and $\mathrm{P} / \mathrm{CF}$ ratio can be used in predicting the stock price in Indonesia stock market.

\section{FINDINGS AND DISCUSSION}

\section{Data Description}

All data in this research such as, stock price, EPS, book value, sales, cash flow and outstanding shares are obtained from Bloomberg terminal as reported in financial report that published in Indonesian Stock Exchange. The number of each model such as price earnings ratio, price to book value, price to sales and price to cash flow are calculated using the formula as stated in chapter III.

There are 86 companies that will be included in this research. (list of companies in appendix). The four models that will be used can be calculated if the denominator such as EPS, book value per share, sales per share and cash flow per share show positive number. So the company which has the negative value of each denominator in each year will be removed from the sample. Overall, in five years the firm year in this research are 286.

Table 5. Five Years Firm Year
\begin{tabular}{|c|c|}
\hline Year & \# of Company \\
\hline 2006 & 51 \\
2007 & 53 \\
2008 & 64 \\
2009 & 56 \\
2010 & 62 \\
\hline Total & 286 \\
\hline
\end{tabular}

To get the average industry ratio, the data will be classified into nine sectors as listed as in Indonesia Stock Exchange. (See Table 6). This average industry will be used to calculate the predicted stock price and after getting the predicted price, it will be compared to the actual price at the end of the year. The difference between predicted and actual price are the prediction error value. 
The difference value could be positive or negative. Positive means that the predicted price is higher than the actual meanwhile the negative means that the predicted price is lower than the actual. In order to rank the accuracy of the predicting model, the prediction error values will be made absolute. The model with the lowest absolute prediction errors is the best model in predicting stock price.

\section{Prediction Errors}

Table 6 will show the results of average predicted error for nonabsolute and absolute 5-year error and absolute yearly error.

Table 6. The average of prediction errors

\begin{tabular}{|c|r|r|r|r|r|}
\hline \multicolumn{7}{|c|}{ 5-Year Error } \\
\hline Year & PE Error & PS Error & PBV Error & PCF Error \\
\hline $2006-2010$ & 1.43 & 2.70 & 1.04 & 2.51 \\
\hline \multicolumn{7}{|c|}{ Absolute 5-Year Error } \\
\hline Year & PE Error & PS Error & PBV Error & PCF Error \\
\hline $2006-2010$ & 1.89 & 3.20 & 1.51 & 2.98 \\
\hline \multicolumn{7}{|c|}{ Absolute Yearly Error } \\
\hline Year & PE Error & PS Error & PBV Error & PCF Error \\
\hline 2006 & 0.39 & 1.18 & 0.74 & 0.92 \\
2007 & 0.68 & 1.20 & 0.64 & 1.35 \\
2008 & 6.06 & 9.62 & 4.34 & 9.77 \\
2009 & 1.13 & 0.78 & 0.78 & 0.74 \\
2010 & 0.54 & 2.13 & 0.66 & 1.09 \\
\hline
\end{tabular}

The table above shows that for non-absolute error value, price to sales ratio has the highest positive error, followed by price to cash flow, price to earnings and the smallest error is price to book value ratio. The best prediction model is the model that shows the smallest amount of error. It means the predicted price has small different value or close with the actual price. From table above, error of PBV ratio shows the smallest value compare to others others. It indicates that in past five years from 2006 until 2010 for non-absolute error value PBV ratio is the best model in predicting stock price.

The average of absolute error shows quite different value of each 5years predicted error. In absolute number, the rank of each ratio is equal to the non-absolute error value but with different amount. In 
absolute, PBV still has the lowest error among other. Based on the calculation, in 2006 until $2010 \mathrm{PBV}$ is the best model in predicting the stock price, second is PE ratio, followed by PCF and PS ratio.

PBV appear as the best model means that in picking a stock, investors notice about the book value of company. Book value is important. It is company's net asset. Book value can describe market values of assets and compared to the earnings it makes. On the other words, investor expect with the amount of asset how much profit will company generate. O'Shaugnessy called P/BV as A Better Gauge of Value. Essentially, investors who buy stocks with low PBV believe they are getting stocks at a price close to their liquidating value, and that they will be rewarded for not paying high prices for assets.

Predited error value for PE ratio is slightly different with PBV. Besides PBV, investor also notice about PE ratio of company. Earning is important for company and investor. For company, earning will be used for running the business. For investor, earning is important because from buying stock they expect to get dividend. PE ratio is the most common measurement of how cheap or expensive it is relative to other stocks and O'Shaugnessy named PE ratio as a separator of the winners and losers.

In whole term for five years, PBV shows the lowest error in predicting stock price. But, based on calculation derived from each year, the model that gives the lowest error was not same in every year. It seen on the Table 6 that from 2006 - 2010 the model that has lowest error are different. In 2006 and 2010, PE has the lowest error in predicting the stock price while PBV best predicting in 2007 and 2008 and PCF in 2009. In past five years, price to sales ratio never shows good in predict the stock price.

From Table 6, PE and PBV show almost similar amount of error. Both have smaller error than PS and PCF. In period of research, price to sales always show the biggest error among others. Perhaps it because of sales is not having direct effect to stock price. Sales is in upper line of income statement, it will be subtracted by company's expense and will be end up with earnings of the company which is more logically to have impact to the stock price. 
In 2008, all of the amount of error increase sharply. In that year, financial crisis hit the global economy. Based on author's calculation the rate of return in stock market Indonesia fell down around $68 \%$. That will trigger the models to make a big error in predicted the stock price because almost all of the stock price in IDX fell down.

In 2009, PCF show the smallest amount of error. But the number is just slightly different with PBV. It was recovery period from the crisis. Cash is important for both company and investor. Cash can be used immediately to cover obligation of company. Company with good cash flow it tends to saver than others. Perhaps thats why investor most likely to notice about the cash flow of company in buying the stock.

\section{Predicted Sectoral Error}

The 86 companies are derived from nine sectors as classified in stock exchange such as: banking, basic industry, consumer, infrastructure, plantation, mining, other industry, property and trade and services. Table below will show which model is perform good in predicting the stock price for different industries.

Table 6. 5-Years Absolute Sectoral Predicted Error

\begin{tabular}{|lrrrrr|}
\hline \multicolumn{5}{c}{ 5-Year Absolute Sectoral Error } \\
\hline \multicolumn{1}{|c|}{ Sectoral } & PE Error & PS Error & PBV Error & PCF Error \\
\hline Banking & 0.61 & 0.56 & 0.59 & 0.92 \\
Basic Industry & 0.85 & 2.21 & 1.99 & $\mathbf{1 . 1 9}$ \\
Consumer & 0.74 & 1.35 & 1.97 & 0.87 \\
Infrastructure & 1.70 & 1.70 & 1.29 & 1.99 \\
Plantation & 1.07 & 1.50 & 1.68 & 2.18 \\
Mining & 4.04 & 1.74 & 1.78 & 3.30 \\
Other Industry & 1.26 & 1.52 & 1.40 & 0.94 \\
Property & 2.16 & 3.09 & 1.20 & 3.25 \\
Trade, Service & 2.28 & 8.94 & 1.46 & 6.41 \\
\hline
\end{tabular}

Table 6 shows that the best predicting model for different industry is not similar. Based on this research, PE ratio was made least error in basic industry, consumer and plantation sector, PBV good in infrastructure, property and trade, services sector, PCF for other industry and PS ratio for mining sector and banking. Based on Table 6 , the best model in predicting stock price are different for each 
sector. Section below will elaborate the consistency of each model in predict the stock price per industry each year.

\section{Banking}

Table 7. Predicted Error of Banking Sector

\begin{tabular}{|c|c|c|c|c|c|}
\hline \multicolumn{6}{|c|}{ Absolute Yearly Sectoral Error } \\
\hline CODE & Year & PE \% Error & PS \% Error & PBV \% Error & PCF \% Ernor \\
\hline \multirow{5}{*}{ Banking } & 2006 & 0.25 & 0.31 & 0.38 & 0.49 \\
\hline & 2007 & 0.28 & 0.34 & 0.21 & 0.81 \\
\hline & 2008 & 1.66 & 1.26 & 1.52 & 2.24 \\
\hline & 2009 & 0.44 & 0.44 & 0.37 & 0.68 \\
\hline & 2010 & 0.41 & 0.43 & 0.45 & 0.37 \\
\hline Average & & 0.61 & 0.56 & 0.59 & 0.92 \\
\hline
\end{tabular}

this research, the four models do not show consistently in predicting the stock price. Each model shows it's ever predicting price best in period of research. This research shows that on average price to sales (or revenue) is the best in predicting price but PBV model appear two times as the best model in year 2007 and 2009.

\section{Basic Industry}

Table 8. Predicted Error of Basic Industry Sector

\begin{tabular}{|ccrrrrr|}
\hline \multicolumn{5}{|c|}{ Absolute Yearly Sectoral Error } \\
\hline CODE & Year & PE \% Error & PS \% Error & PBV \% Error & PCF \% Error \\
\hline & 2006 & 0.42 & 1.50 & 1.37 & $\mathbf{0 . 9 0}$ \\
Basic Industry & 2007 & 0.39 & 1.20 & $\mathbf{0 . 4 5}$ & $\mathbf{0 . 5 0}$ \\
& 2008 & 2.50 & 5.94 & 5.74 & $\mathbf{3 . 0 5}$ \\
& 2009 & 0.67 & 1.20 & 1.40 & $\mathbf{0 . 9 4}$ \\
& 2010 & 0.25 & 1.19 & 1.01 & $\mathbf{0 . 5 7}$ \\
\hline Average & & 0.85 & $\mathbf{2 . 2 1}$ & 1.99 & 1.19 \\
\hline
\end{tabular}

For basic industry sector, PE ratio is consistently appearing as the best model in predicting the stock price. It appears every year in period of this research. Compare to other models, in average PE ratio's error is less than 1 but other model's are not. The spread of PE's error compare to other is quite wide, which means that PE ratio is the best model to use in basic industry. For this industry, investors notice that earning is the most important thing to consider in determine the decision for buying a stock. As stated in chapter 2, Damodaran explained that one of the more intuitive ways to think of the value of any asset is as a multiple of the earnings that assets generate which means when buying a stock, it is common to look at the price paid as a multiple of the earnings per share generated by the company. 


\section{Consumer}

Table 9. Predicted Error of Consumer Sector

\begin{tabular}{|c|c|c|c|c|c|}
\hline \multicolumn{6}{|c|}{ Absolute Yearly Sectoral Error } \\
\hline CODE & Year & PE \% Error & PS \% Error & PBV \% Error & PCF \% Error \\
\hline \multirow{5}{*}{ Consumer } & 2006 & 0.93 & 2.35 & 2.12 & 1.25 \\
\hline & 2007 & 0.32 & 0.80 & 1.61 & 0.27 \\
\hline & 2008 & 1.55 & 2.82 & 4.69 & 1.97 \\
\hline & 2009 & 0.50 & 0.37 & 0.83 & 0.49 \\
\hline & 2010 & 0.40 & 0.41 & 0.60 & 0.38 \\
\hline Average & & 0.74 & 1.35 & 1.97 & 0.87 \\
\hline
\end{tabular}

Alike with basic industry, consumer sector also shows that PE ratio is the best in predict the stock price. PS ratio and PCF ever predict once within period, but the number of error is slightly different with errors of PE. Companies that include in this sector are company who sell consumer goods such as Unilever, Indofood, Gudang Garam, and Kalbe Farma. These company have consistent record for paying dividend. It means that earning is important for investor who wants to buy the stock of these company. O'Shaughnessy mentioned that for many on Wall Street, buying stocks with low P/E is the one true faith. Investors who buy stocks with low PE think they're getting a bargain. So, with buying the stocks investor which means investor is a stakeholder of company, they also can get another advantage which is dividend payment.

\section{Infrastructure}

Table 10. Predicted Error of Infrastructure Sector

\begin{tabular}{|crrrrrr|}
\hline \multicolumn{7}{|c|}{ Absolute Yearty Sectoral Error } \\
\hline CODE & Year & PE \% Error & PS \% Error & PBV \% Error & PCF \% Error \\
\hline & 2006 & 0.48 & $\mathbf{2 . 1 9}$ & $\mathbf{0 . 7 0}$ & $\mathbf{0 . 9 8}$ \\
& 2007 & $\mathbf{1 . 1 7}$ & $\mathbf{0 . 7 3}$ & 0.45 & $\mathbf{0 . 5 7}$ \\
Infrastructure & $\mathbf{2 0 0 8}$ & $\mathbf{3 . 9 8}$ & $\mathbf{3 . 4 7}$ & 3.23 & $\mathbf{7 . 1 1}$ \\
& $\mathbf{2 0 0 9}$ & $\mathbf{2 . 4 9}$ & $\mathbf{1 . 6 5}$ & $\mathbf{1 . 4 4}$ & 0.94 \\
& $\mathbf{2 0 1 0}$ & $\mathbf{0 . 3 6}$ & $\mathbf{0 . 4 4}$ & $\mathbf{0 . 6 3}$ & 0.34 \\
\hline Average & & 1.70 & 1.70 & 1.29 & 1.99 \\
\hline
\end{tabular}

Infrastructure sector consist of companies that develop the infrastructure in Indonesia. Telecommunication, toll road and transportation are included in this sector. This research show that PBV and PCF are predicts best for two times within period. But, in average 
PBV show the least error among others. Book value is also assets minus liabilities that are equal to net assets. Company in this sector need many fixed asset to support their business. This type of busines needs big amount of funding and it usualy generate from loan. High liabilities can make book value become lower and investor notice that the book value is important in this industry.

\section{Plantation}

Table 11. Predicted Error of Plantation Sector

\begin{tabular}{|ccccccc|}
\hline \multicolumn{7}{|c|}{ Absolute Yearly Sectoral Error } \\
\hline CODE & Year & PE \% Error & PS \% Error & PBV \% Error & PCF \% Error \\
\hline & $\mathbf{2 0 0 6}$ & 0.39 & $\mathbf{1 . 1 2}$ & $\mathbf{0 . 8 2}$ & $\mathbf{1 . 1 5}$ \\
& $\mathbf{2 0 0 7}$ & 0.36 & $\mathbf{0 . 5 5}$ & $\mathbf{0 . 7 0}$ & $\mathbf{4 . 4 9}$ \\
Plantation & 2008 & 3.31 & 3.97 & $\mathbf{5 . 1 7}$ & $\mathbf{3 . 6 4}$ \\
& $\mathbf{2 0 0 9}$ & $\mathbf{0 . 5 1}$ & $\mathbf{0 . 7 4}$ & $\mathbf{0 . 5 3}$ & 0.44 \\
& $\mathbf{2 0 1 0}$ & 0.77 & $\mathbf{1 . 1 3}$ & $\mathbf{1 . 2 1}$ & $\mathbf{1 . 2 0}$ \\
\hline Average & & 1.07 & $\mathbf{1 . 5 0}$ & $\mathbf{1 . 6 8}$ & $\mathbf{2 . 1 8}$ \\
\hline
\end{tabular}

For plantation sector, almost in every year PE is the model which is show the least error. Only in 2009, PCF is the best in predicting the stock price. Plantation industry in Indonesia is dominated by palm oil and rubber. The players in this sector quite various such as Astra Agro Lestari, Bakrie Plantation, London Sumatera, Sampoerna Agro, etc. In average, $\mathrm{PE}$ is the best model to be used in predicting this sector's price.

\section{Mining}

Table 12. Predicted Error of Mining Sector

\begin{tabular}{|c|c|c|c|c|c|}
\hline \multicolumn{6}{|c|}{ Absolute Yearly Sectoral Error } \\
\hline CODE & Year & PE \% Error & PS \% Error & PBV \% Error & PCF \% Error \\
\hline \multirow{5}{*}{ Mining } & 2006 & 0.18 & 0.42 & 0.49 & 0.41 \\
\hline & 2007 & 0.58 & 0.60 & 0.55 & 0.61 \\
\hline & 2008 & 18.18 & 6.37 & 6.70 & 13.82 \\
\hline & 2009 & 0.67 & 0.52 & 0.58 & 1.22 \\
\hline & 2010 & 0.60 & 0.80 & 0.58 & 0.46 \\
\hline Average & & 4.04 & 1.74 & 1.78 & 3.30 \\
\hline
\end{tabular}

For mining industry, in average, PS ratio made the least error. Within period, every models ever show the best but not consistent. PE ratio in this sector is performing worst among in other sector. During the 
financial crisis in 2008, PE ratio made the biggest value of error in predicting stock price. Different to PS ratio, this ratio has the least error in average and also in 2008 where the financial crisis occurred. Revenue for companies in this industry are depends on fluctuation of commodity price. They set the prie for coal, gold, oil, nickel, etc based on global price. Because of the influence of global price, sales is important to value these company. Mining sector is quite risky maybe that's why investor used this model in predicting stock price for this industry. As Brown explained, sales information is subject to less manipulation than any other data item and O'Shaughnessy called price to sales ratio as The King of the Value Factors.

\section{Other Industry}

Table 13. Predicted Error of Other Industry Sector

\begin{tabular}{|ccc|c|rr|}
\hline \multicolumn{7}{|c|}{ Absolute Yearly Sectoral Error } \\
\hline CODE & Year & PE \% Error & PS \% Error & PBV \% Error & PCF \% Error \\
\hline & $\mathbf{2 0 0 6}$ & $\mathbf{1 . 0 8}$ & $\mathbf{0 . 4 2}$ & 0.35 & $\mathbf{0 . 6 8}$ \\
Other Industry & $\mathbf{2 0 0 7}$ & $\mathbf{2 . 5 4}$ & $\mathbf{1 . 0 4}$ & 0.93 & 0.93 \\
& $\mathbf{2 0 0 8}$ & 1.62 & $\mathbf{4 . 6 6}$ & $\mathbf{4 . 2 7}$ & $\mathbf{2 . 0 2}$ \\
& $\mathbf{2 0 0 9}$ & 0.70 & 0.70 & 0.70 & 0.70 \\
& $\mathbf{2 0 1 0}$ & $\mathbf{0 . 3 7}$ & $\mathbf{0 . 7 9}$ & $\mathbf{0 . 7 3}$ & 0.35 \\
\hline Average & & $\mathbf{1 . 2 6}$ & $\mathbf{1 . 5 2}$ & $\mathbf{1 . 4 0}$ & $\mathbf{0 . 9 4}$ \\
\hline
\end{tabular}

In this industry, PCF shows the least error in average. But, within research period PBV and PCF ever appear equally as the best model in predicting the stock price. In this research, companies that include in this sector are ASII, GJTL, DOID and ADMG. In 2009, GJTL, DOID and ADMG had negative earning so the error only for ASII. All model show exactly same number of error. Company under this sector use fixed assets most in running the business. For example Astra International. One of ASII's subsidiary, United Tractor has many fixed assets because its business is provide heavy equipment. Companies under this sector also need factories and machinery which is will be classified as fixed asset. It called capital expenditure to get and maintain these assets. This capex will depend on company's cash flow. 


\section{Property}

Table 14. Predicted Error of Property Sector

\begin{tabular}{|rcrrrrr|}
\hline \multicolumn{7}{c|}{ Absolute Yearly Sectoral Error } \\
\hline CODE & Year & \multicolumn{1}{c|}{ PE \% Error } & PS \% Error & PBV \% Error & PCF \% Error \\
\hline & $\mathbf{2 0 0 6}$ & 0.10 & $\mathbf{0 . 9 8}$ & $\mathbf{0 . 3 9}$ & $\mathbf{0 . 3 0}$ \\
& $\mathbf{2 0 0 7}$ & $\mathbf{0 . 9 0}$ & $\mathbf{0 . 5 9}$ & 0.22 & $\mathbf{3 . 1 1}$ \\
Property & $\mathbf{2 0 0 8}$ & $\mathbf{8 . 5 5}$ & $\mathbf{1 1 . 4 6}$ & 4.37 & $\mathbf{1 0 . 9 2}$ \\
& $\mathbf{2 0 0 9}$ & 0.58 & $\mathbf{1 . 0 1}$ & $\mathbf{0 . 6 1}$ & 0.58 \\
& $\mathbf{2 0 1 0}$ & 0.65 & $\mathbf{1 . 3 8}$ & $\mathbf{0 . 4 1}$ & $\mathbf{1 . 3 2}$ \\
\hline Average & & $\mathbf{2 . 1 6}$ & $\mathbf{3 . 0 9}$ & $\mathbf{1 . 2 0}$ & $\mathbf{3 . 2 5}$ \\
\hline
\end{tabular}

In property sector, PBV appear as the best model in predicting stock price in average. The characteristic of this sector almost similar with infrastructure sector. In infrastructure sector, PBV also appear as the best model. For this sector, the most important thing is landbank. The business is how is company manage the landbank to make profit. The landbank is part of asset which is directly affect book value of company. If the error are splitted to each year, PE ratio shows that it appear as the best model more than PBV. It seems investors also notice on earnings before buy a stock from this sector.

\section{Trade and Services}

Table 15. Predicted Error of Other Industry Sector

\begin{tabular}{|ccrrrrr|}
\hline \multicolumn{7}{c|}{ Absolute Yearly Sectoral Error } \\
\hline \multicolumn{1}{|c}{ CODE } & Year & PE \% Error & PS \% Error & PBV\% Error & PCF \% Error \\
\hline & $\mathbf{2 0 0 6}$ & 0.54 & $\mathbf{2 . 0 7}$ & $\mathbf{0 . 8 2}$ & $\mathbf{2 . 3 9}$ \\
Trade, Service & $\mathbf{2 0 0 7}$ & $\mathbf{0 . 4 1}$ & $\mathbf{3 . 4 4}$ & 0.81 & 1.60 \\
& $\mathbf{2 0 0 8}$ & $\mathbf{6 . 6 7}$ & 29.05 & 4.43 & $\mathbf{2 4 . 1 5}$ \\
& $\mathbf{2 0 0 9}$ & $\mathbf{2 . 8 8}$ & $\mathbf{0 . 4 0}$ & $\mathbf{0 . 5 9}$ & 0.23 \\
& $\mathbf{2 0 1 0}$ & $\mathbf{0 . 8 8}$ & $\mathbf{9 . 7 3}$ & 0.64 & $\mathbf{3 . 6 8}$ \\
\hline Average & & $\mathbf{2 . 2 8}$ & $\mathbf{8 . 9 4}$ & $\mathbf{1 . 4 6}$ & 6.41 \\
\hline
\end{tabular}

As in property and infrastructure sector, in this sector PBV also appear as the best model in predicting stock price. In average, PBV made the least error and within period it appears most among others. PS ratio never shows good in predict stock price in this sector. This sector consists of various type of company such as Service Company, Retail Company, and Investment Company. The characteristic of those company almost similar with banking and infrastructure sector which is have PBV as the best model in predicitng the stock price. 


\section{Hypo research Testing for Absolute Predicted Error}

After absolute predicted error has been computed, it will be tested statistically to get the most accurate model in predicting stock price. The author use one-way ANOVA approach where the purpose of this method is to determine if more than two population means are equal. In this research, four populations' means are tested (PE, PBV, PS and PCF). Table below is the result of Anova.

Table 16. One Way Anova Result

\begin{tabular}{|crrr|}
\hline Relative Valuation & Mean & Std. Deviation & $\begin{array}{c}\text { F Stat } \\
(p \text {-value) }\end{array}$ \\
\hline PE Error & 1.89 & 26.27 & 2.6029 \\
PS Error & 3.20 & 136.74 & \\
PBV Error & 1.51 & 8.03 & $(0.051)$ \\
PCF Error & 2.98 & 124.78 & \\
\hline
\end{tabular}

Table 16, shows the mean of error from each model is different. The $\mathrm{F}$ Stat and p-value number is determining that the variances between the means of two populations are significantly different. It means the result of calculation of error for relative valuation model in this research is significant. Based on result of Table 62, the average of each error are not similar.

Statistical test show that PBV is proved as the best model in predicting stock price. Overall, the result shows PBV is the best model, however, each industry has its own best model which is suit with company's characteristic.

\section{CONCLUSION}

\section{Conclusion}

The research findings can be concluded as follow. Firstly, in aggregate observed period, PBV appears as the best model in predicting LQ45 stock price in Indonesian equity market. However, the yearly analysis concludes that time is an important factor to consider in nominating the best predictor since the best predictor in each year is not the same (PE for 2006 and 2010, PBV for 2007 and 2008 and PCF for 2009). Another factor to consider is sector (industry). The result shows that each industry has its unique best 
predictor, in which $\mathrm{PE}$ and $\mathrm{PBV}$ are the best predictors for three sectors, PS is the best predictor for tqo sectors and PCF is the best predictor for one sector. Since mixed results is found in indentifying the best predictor, the hyporesearch testing concludes that the prediction errors generated by the ratios are different.

\section{Managerial Implication}

The result implies that time and sector are two important factors that investors should consider when using Relative Valuation Model to value the LQ45 stocks. company in order to avoid buying a stock which is overvalued. Although PBV appears to be the best predictor, it is suggested that investors should use another ratio that shows as the best predictors in the sectors.

\section{REFERENCES}

Aydogan, Kursat. 2000. P/E and PRICE-to-BOOK RATIOS as PREDICTORS of STOCK RETURNS IN EMERGING EQUITY MARKETS, [Online]

Available: http://www.bilkent.edu.tr/ aydogan/emqpaper.pdf [2011, November 15]

Bodie, Zvi, Kane, Alex, Marcus, Alan J. 2009, Investments, $8^{\text {th }}$ ed., McGraw Hill.

Brown, Keith C., Reilly, Frank K. 2009, Analysis of Investments and Management of Portfolios, $9^{\text {th }}$ ed., South-Western Cengage Learning.

Chairatanawan, Yongyoot. 2008, Predictive Power of Financial Ratios to Stock Return in Thailand, [Online] Available: http://www.iis.ru.ac.th/download/Journal/pdf\%20vol2(2)/8.\%2 OChairatanawan.pdf [2011, June 15]

Damodaran, Aswath. 2006, Valuation: Security analysis for investment and corporate finance, $2^{\text {nd }}$ ed., John Wiley \& Sons, Inc.

Fei, Goh Chin. 2011. Equity Valuation Using Multiples: An Empirical Study on Plantation Sector, [Online] Available: 
http://gupea.ub.gu.se/bitstream/2077/26350/1/gupea_2077_26 350_1.pdf [2011, November 15]

Lewellen, Jonathan. 2002, Predicting return with financial ratios, [Online] Available: http://mba.tuck.dartmouth.edu/pages/faculty/jon.lewellen/docs /FinancialRatios.pdf [2011, June 15]

Minjina, Dragos Ioan. 2009. Relative Performance of Valuation Using Multiples. Empirical Evidence on Bucharest Stock Exchange, [Online] Available: http://www.rfb.ase.ro/articole/RFB7.pdf [2011, November 15]

Omran, M.F. 2009. Favorable clientele effect and the valuation multiples of Islamic financial institutions in the United Arab Emirates. Nile University. Egypt

O'Shauhnessy, James P. 1998, What Works on Wall Street, McGraw Hill - New York

Park, Young S. 2003. An Empirical Study on the Relevance of Applying Relative Valuation Models to Investment Strategies in the Japanese Stock Market, Sogang University. [2011, November 15]

Penman, Stephen H. 2007, Financial Statement Analysis and Security Valuation, $3^{\text {rd }}$ ed., McGraw Hill.

Sanjay, Sehgal. 2010. EQUITY VALUATION USING PRICE MULTIPLES: EVIDENCE FROM INDIA , [Online] Available: http://web.usm.my/journal/aamjaf/vol\%206-1-2010/6-1-5.pdf [2011, November 15]

Schreiner, Andreas. 2007. Equity Valuation Using Multiples: An Empirical Investigation, [Online] Available: http://www1.unisg.ch/www/edis.nsf/SysLkpByIdentifier/3313/ \$FILE/dis3313.pdf [2011, November 15]

Schreiner, Andreas. 2007. Multiples and Their Valuation Accuracy in European Equity Markets , [Online] Available: http://asaha.com/ebook/zMjMzMTIx/Multiples-and-TheirValuation-Accuracy-in-European-Equity-Markets.pdf [2011, November 15] 
Teweles, Richard J. 1998, Bradley, Edward S. The Stock Market, $7^{\text {th }}$ ed., John Wiley \& Sons, Inc.

Turk, Adam F., Margaret Chapman. 2006. The Effect of Financial Ratios and Market Hype on Short Term Stock Prices, [Online] Available:

$\underline{\text { http://digitalcommons.iwu.edu/cgi/viewcontent.cgi? article }=10}$ $35 \&$ context=econ_honproj\&sei-

redir=1\#search=\%22The+Effect+of + Financial + Ratios + and $+\mathrm{M}$ arket+Hype+on+Short+Term+Stock+Prices\%22 [2011, June 15]

Vorek, Marian. 2009. DOES HIGH PRICE EARNINGS RATIO PREDICT FUTURE FALLS OF STOCK PRICE?, [Online] Available:

http://www.icabr.com/fullpapers/Vorek\%20Mari\%E1n.pdf [2011, November 15]

www.bi.go.id

www.ibpa.co.id 